\title{
Synthesis, Biological Activity, and In silico Study of Bioesters Derived from Bixin by the CALB Enzyme
}

\author{
Aluísio Marques da Fonseca ${ }^{1, *(D)}$, Ícaro Bezerra de Freitas 2 (D), Neidelenio Baltazar Soares 2 (D), Francisco \\ Aurecio Morais de Araújo $^{2}$ (D), Eduardo Menezes Gaieta ${ }^{2}$ (D), José Cleiton Sousa dos Santos ${ }^{3}$ (D), Antonio \\ Carlos Nogueira Sobrinho ${ }^{4}$ (D), Emmnauel Silva Marinho ${ }^{5}$ (D), Regilany Paulo Colares ${ }^{2}$ (i)
}

1 Academic Master in Sociobiodiversity and Sustainable Technologies, Institute of Engineering and Sustainable Development, University of International Integration of Afro-Brazilian Lusophony, Auroras Campus, ZIP 62790970, Redenção, CE, Brazil; aluisiomf@unilab.edu.br (A.M.F.);

2 Institute of Exact Sciences and Nature, University of International Integration of Afro-Brazilian Lusophony, ZIP 62790970, Redenção, CE, Brazil.; bezerraicaro@ymail.com (I.B.F.); neidileniosoares@gmail.com (N.B.S.); aureciomorais@gmail.com (F.A.M.A.); eduardomenezesgaieta@gmail.com (E.M.G.); regilany @ unilab.edu.br (R.P.C.);

3 Institute of Engineering and Sustainable Development, University of International Integration of Afro-Brazilian Lusofonia, Auroras Campus, ZIP 62790970, Redenção, CE, Brazil; jcs@unilab.edu.br (J.C.S.S.);

4 Course of Biological Sciences, Faculty of Education, Sciences and Letters of Iguatu, State University of Ceará, ZIP 63.502253, Iguatu, CE, Brazil; caiosobrinho@yahoo.com.br (A.C.N.S.);

5 Faculty of Philosophy Dom Aureliano Matos, State University of Ceará, ZIP 62.930.000, Limoeiro do Norte, CE, Brazil; emmanuel.marinho@uece.br (E.S.M.);

* Correspondence: aluisiomf@unilab.edu.br (A.M.F.);

Received: 17.08.2021; Revised: 29.09.2021; Accepted: 2.10.2021; Published: 24.10.2021

\begin{abstract}
Biocatalysis is a branch of biotechnology that aims at the chemical transformation of a compound by using enzymes of known specificity. There are already several studies that use combinations of organic origin and enzymes as catalysts. The enzymatic sources are diverse and can be found in microorganisms, animals, vegetables, or commercial (enzymes isolated). The enzyme Candida antarctica lipase B (CALB), of microbial origin, commercially available and with high catalytic activity, can perform esterification reactions, obtaining expressive results. These biocatalytic reactions can contribute to the development of energy products, such as biofuels and pharmaceuticals, such as cosmetics and pharmaceuticals. In this context, the present project aims to esterify with the enzyme Candida antarctica lipase B (CALB), a natural product known as bixin, a dye extracted from the pericarp of annatto seeds (Bixa orellana L.) to verify its biological properties and in silico evidence of its cholesteric activity.
\end{abstract}

Keywords: biocatalysis; bioesterification; bixin.

(c) 2021 by the authors. This article is an open-access article distributed under the terms and conditions of the Creative Commons Attribution (CC BY) license (https://creativecommons.org/licenses/by/4.0/).

\section{Introduction}

Bixin is the pigment of annatto present at the top of the achiote seed (Bixa orellana), a rapidly growing shrub that reaches 4-6 meters high, robust in showy appearance flowers whose color depends on the variety. An arillus is observed on its seed surface that has several substances besides the characteristic red pigment. This arillus represents about $5 \%$ to $10 \%$ of the weight of the seed, of which the carotenoid bixin represents only $30 \%$, Fig. 1, of reddishyellow color and liposoluble, being a monomethyl ester of a cis-norbixin carboxylic acid having nine conjugated oleiphic bonds, with one in the cis [1-3]. 


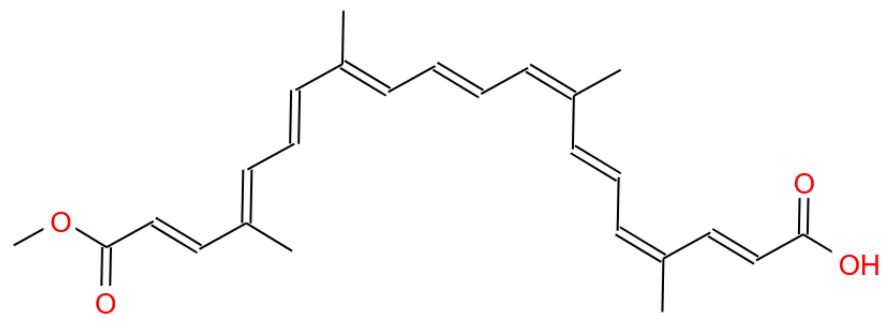

Figure 1. Z-Bixin 2D structure.

This molecular structure has an isoprenoid chain (alternating double bonds), naturally with cis geometric isomers in $\mathrm{C}-16$, having a carboxylic acid group and an ester group at each chain; bixin is formed by oxidative degradation of C40 carotenoids. This substance is known for its stability to light, oxidation, $\mathrm{pH}$ changes, temperature up to $100^{\circ} \mathrm{C}$ [4]. This makes it possible to perform bioreactions by enzymatic means [5].

The term biocatalysis covers the process in which a biological catalyst is used to convert a substrate into a limited number of enzymatic steps [6, 7]. These enzymes act as specific and chiral catalysts due to their high versatility in performing various types of organic reactions [8]. Biocatalytic reactions are usually safe and may occur in mild conditions of temperature, $\mathrm{pH}$ close to neutral, thus minimizing isomerization, racemization, and epimerization of stereogenic centers, which are frequent when using conventional catalysts [9, 10].

Lipases can be animal (pancreatic, hepatic, and gastric), microbial (bacteria and fungi), and plant origin, with variation in their catalytic properties. They are considered one of the enzymes most used in biocatalytic processes. Lipases of microbial origin are still the most used. However, the study of plant sources (stem, leaf, and latex) has grown in recent years [11, 12].

In addition to hydrolysis, lipases can also catalyze other types of chemical reactions such as esterification, transesterification (interesterification, alcoholysis, and acidolysis), aminolysis (amide synthesis), and lactation [13-15].

Currently, the immobilized enzyme Candida antarctica lipase B (Novozym 453 or CALB), of microbial origin, is considered one of the most used in bioprocesses because it has high catalytic activity [16]. Recent articles [17] report this enzyme's use in the catalysis of the esterification reaction of various substrates, obtaining very satisfactory results. Therefore, there are also reports of enzymatic hydrolysis of fatty acid esters of red pepper carotenoids (Capsicum annum L.) and golden flowers (Tagetes erecta L.) by this lipase [18, 19]. This enzyme showed a higher esterification index with these acids uncommon in nature than linear chain acids, such as myristic acid (C14:0) [20, 21].

Because it is easy to extract and obtain, recent studies have reported several biological and pharmacological activities of Z-bixin and its derivatives [22-24]. Including in vitro evaluation of the inhibitory activity of the enzyme acetylcholinesterase (AChE) $[25,26]$.

Alzheimer's disease (AD) is a neurological pathology of progressive degenerative nature that results in impaired memory and behavior [27]. The treatment strategies are based on the cholinergic hypothesis, which postulated that memory deficiencies in patients suffering from this disease result from a deficit of cholinergic function in the brain. Cholinergic neurotransmission is significantly affected in patients with Alzheimer's disease [28]. One of the most promising approaches to treating this disease is to increase the level of acetylcholine in the brain using acetylcholinesterase inhibitors (AChE) [29-31]. Therefore, AD's clinical treatment involves reversible cholinesterase inhibitors in clinical trials to treat Alzheimer's disease [30, 32]. 
Anticholinesterase may interact with the central cholinergic system to improve patients' memory and cognitive deficits by decreasing acetylcholine's degradation at the synaptic site of the brain. However, the therapeutic window is small, and the acetylcholinesterase inhibitor effect (AChE) test on erythrocytes has been proposed to guide the efficacy and safety of putative therapies [30].

In medicinal chemistry, these simulations involve representing and manipulating active chemical structures with the primary objective in the rational planning of drugs [33]. Molecular modeling systems have been developing over the years, thanks to technological evolution and computer graphics, considering that the results obtained are converted into images that significantly improve object analysis [34, 35].

The calculation methods are based on theoretical chemistry being divided into Molecular Mechanics (MM), Quantum Mechanics (QM), and molecular anchorage that helps us understand the relationship of structure with biological activity [36]. For in silico tests, it is widespread to use more than one method to describe a process for optimizing a linker or receiver [35].

Molecular Mechanics (MM), also known mathematically by the force field method, is commonly used in obtaining macromolecular and enzymatic models, given the shorter computation time required in the process [37]. We can highlight that it is a simple method that is based on the relativistic positions of atoms with the nucleus, determined by the forces of attraction and repulsion that act on the structure, being the total potential energy $\left(E_{t o t a l}\right)$ the sum of all energies that operate in the system [38, 39]. Calculations performed by Quantum Mechanics (QM) use resolutions in the wave function of the Schroëdinger equation [40-42]. For small molecular systems, the process takes into account the Bohr-Oppenheimer approximation [43], calculating the wave functions of the nucleus and electrons separately ( $a b$ initio), which requires a high computational cost and time [44]. Using experimental (semiempirical) parameters in the equation's resolution facilitates some integrals. It makes it possible to find results closer to the actual value [45].

Molecular docking is widely used in molecular modeling studies applied to biomolecule analysis and drug development [46]. The method simulates a flexible ligand optimized with a rigid receptor by the genetic process [47] with an active site defined by a parameterized grid with specific coordinates and space adjusted to obtain a better conformational posture of the receptor-ligand complex [48].

Therefore, this work aims to present biocatalysis (via immobilized enzyme Candida antarctica lipase B), biological activity, and a brief in silico study of bixin bioderivatives against the ache enzyme molecular anchorage using galantamine ${ }^{\circledR}$ [49-51] as a positive pattern.

\section{Materials and Methods}

\subsection{Botanical material.}

The plant material was collected and washed with distilled water, crushed in a blender (Philips ${ }^{\circledR}$ ), and stored $1000 \mathrm{~mL}$ beaded. Soon after, left dry in greenhouse incubator EIP-010 $\left(\right.$ Caltech $\left.{ }^{\circledR}\right)$ with circulating air to avoid saturation with water vapor released from the drying material and exposed to a constant temperature of $40^{\circ} \mathrm{C}$ for 48 hours for drying. 


\subsection{Botanical identification.}

The samples of annatto seeds were acquired, in Fortaleza, in the garden of medicinal plants, in Ceará. Professor Iracema Loiola authenticated the type. The specimen, whose exsiccate, was deposited in the Prisco Bezerra Herbarium (EAC) in the Department of Biology, Federal University of Ceará (UFC) with the \#EAC0059302 voucher.

\subsection{Extraction of bixin.}

From the adaptation of the literature [52], and extraction was made by organic solvent, which is repeated five times with the same material. The solvent used was gradient between chloroform $\left(\mathrm{CHCl}_{3}\right)$ and $n$-hexane $\left(\mathrm{C}_{6} \mathrm{H}_{14}\right)$ in the proportion of $1: 1$ in a volume of $700 \mathrm{~mL}$, where the material with mass $576.40 \mathrm{~g}$, where it was immersed around 48 hours in the solution, was subsequently performed a simple filtration using a steel sieve to remove the grains, and immediately after a vacuum filtration to remove the suspended solids from which a reddishcolored solid was obtained. Soon after, the solution was extraction, by a rota-evaporator under reduced pressure, getting a reddish-colored extract.

\subsection{Products obtained by bioreaction.}

The reaction mixture was submitted to the following processes: fractionation in filter chromatographic column, separation of constituents by column chromatography, and finally, purification by recrystallization.

\subsection{Commercial enzyme testing.}

The initial tests were performed with the immobilized enzyme Candida antarctica lipase B (Novozym 453 or CALB), microbial origin, commercially available, and high catalytic activity.

\subsection{Enzymatic catalysis.}

The methodology used for enzymatic catalysis was an adaptation [53, 54]; a reaction was made in a water bath at $200 \mathrm{rpm}$, at $40^{\circ} \mathrm{C}$ for 8 hours. Four alcohols (methanol, ethanol, propanol, and butanol) were used, as shown in Scheme 1. In each sample, $50 \mathrm{mg}$ of bixin, 10 mg of CALB enzyme (Novozym 435), and $20 \mu$ of the donation alcohol were added.

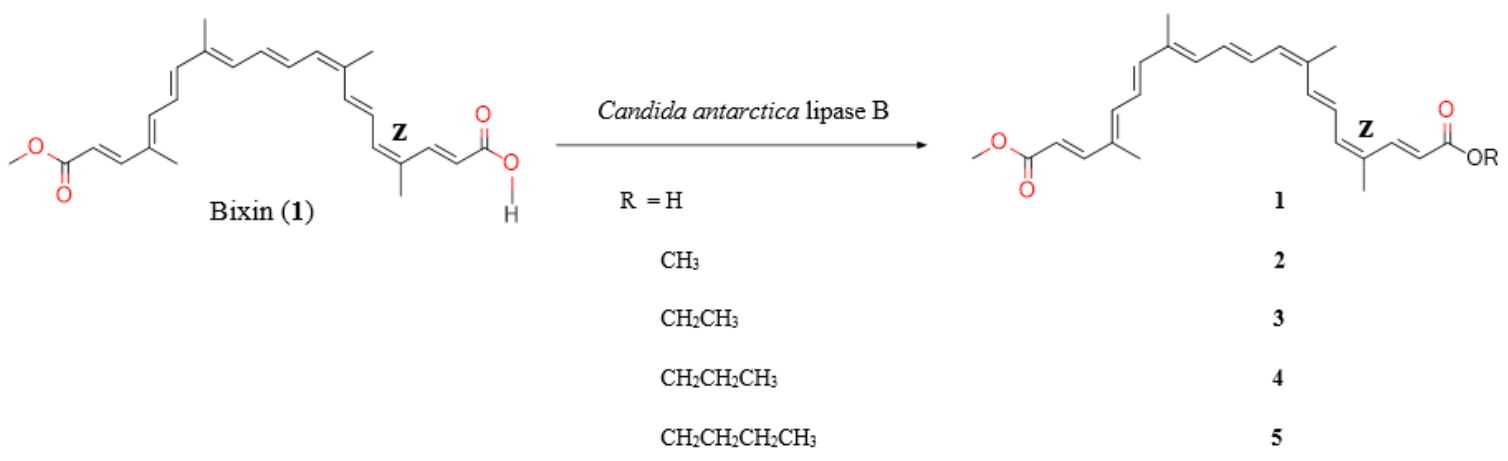

Scheme 1. Reaction of bixin (1) with lipase. 
2.6.1. Yield from the acidity index $\left(\mathrm{A}_{\mathrm{i}}\right)$.

The yield from the acidity index $\left(\mathrm{A}_{\mathrm{i}}\right)$ was used to determine whether biocatalysis occurred. The methodology used was an adaptation of the literature $[55,56]$, where a $70 \%$ commercial alcohol neutralization was performed with sodium hydroxide $(\mathrm{NaOH}) 0.1 \mathrm{~mol}$. $\mathrm{L}^{-1}$. Soon after, a simple titration of all bioproducts was made. The acidity index calculation is described in Equation 1, while the conversion values in esters were determined from Equation 2.

$$
\begin{array}{cc}
A i=\text { molarity }(\mathrm{NaOH}) * M M \text { sample } * F * \frac{V \text { tritation }}{m \text { reactional }} & \text { Equation } 1 . \\
\text { Convertion }(\%)=\frac{A i-A i b}{A i b} \times 100 & \text { Equation } 2 .
\end{array}
$$

2.6.2. Absorption spectroscopy in the infrared region.

The absorption spectra in the infrared (IR) region were obtained from the samples' arrangement solubilized in $\mathrm{CH}_{3} \mathrm{OH}$ in potassium bromide $(\mathrm{KBr})$ tablets. The analyses were performed on an FT-IR 100 PerkinElmer spectrophotometer in the region from 4000 to 650 $\mathrm{cm}^{-1}$ at the Northeast Mass Spectrometry Laboratory, belonging to the Department of Organic and Inorganic Chemistry of the Federal University of Ceará.

\subsection{In vitro tests.}

\subsubsection{Antioxidant activity.}

The extract and products from enzymatic catalysis were diluted in methanol at seven different concentrations.

The methodology used was an adaptation [57, 58]. Each test tube contained $2 \mathrm{~mL}$ of sample, then $2.0 \mathrm{~mL}$ of (2,2-diphenyl-1-picryl-hydrazyl) DPPH solution $(60 \mu \mathrm{M})$ in methanol was added to the samples in the absence of light, where the reaction process waited 30 minutes. The samples were analyzed in the T80 UV/VIS model spectrometer in triplicate [59].

\subsection{Ecotoxicity}

To determine the ecotoxicity of bixin and its bioderivatives in the biological environment, the lethal dose of the same was selected, the literature methodology was adopted [60], and adaptations [61] with the use of nautilus of Artemia salina. The method was divided into three steps:

\subsubsection{Stage: bioassay with Artemia salina.}

Initially, it was necessary to prepare a saline solution $(\mathrm{NaCl})$, in the proportion $30 \mathrm{~g} / \mathrm{L}$, the $\mathrm{pH}$ was reappropriated with a solution of sodium hydroxide $(\mathrm{NaOH}) 5 \%$, leaving its $\mathrm{pH}$ at 8; after the preparation of the solution, we used a beaker of $2.00 \mathrm{~L}$, being the container externally coated with white A4 paper and aluminum foil, to allow the best visualization of the larvae. Therefore, the saline solution previously prepared in a beaker, about $1.50 \mathrm{~L}$, was added, then about $50 \mathrm{mg}$ of cysts of the species Artemia salina were added to the solution. The lighting of Artemia salina in the solution was by a $5 \mathrm{~W}$ led lamp positioned under the container to be well lit. The incubation period was around 48 hours. 
2.8.2. Step: preparation of samples with Artemia salina.

After the nauplius hatching, a Pasteur pipette was used to capture and transfer ten larvae to test tubes, which contained $4.0 \mathrm{~mL}$ of the extract in its interior diluted in the same saline solution prepared for hatching. The tests were performed in triplicate for each extract/compound concentration of this analysis. The concentrations used for each sample were $\left(1.00 ; 0.50 ; 0.250 ; 0.125 ; 0.062 ; 0.031 \mathrm{mg} . \mathrm{mL}^{-1}\right)$, and all samples were dissolved in the same saline solution of cultivation in decreasing concentration. Using the method to calculate the lethal dose (LD), referring the extract or compound of low toxicity when the lethal dose is less than $50 \%\left(\mathrm{LD}_{50}\right)$ greater than $500 \mathrm{mg} \cdot \mathrm{mL}^{-1}$; Moderate toxicity to $\mathrm{LD}_{50}$ between 100 and 500 $\mu \mathrm{g} \cdot \mathrm{mL}^{-1}$ and quite toxic when this value of $\mathrm{LD}_{50}$ is less than $100 \mu \mathrm{g} \cdot \mathrm{mL}^{-1}$, according to a study in the literature [62].

\subsubsection{Step: count of Artemia salina.}

The counting of this biological assay, made through the first 24 and 48 hours after pipetting the larvae in the test tubes with solutions/extract in the respective concentrations, considering the living nauplius all those who presented movements inside the box by attraction by light, and dead to those who were at the bottom of the pipes without any action. An augment glass was used for better visualization and naupliar counting.

2.9. In silico study.

\subsubsection{Molecular simulation.}

The simulation was performed using the code AutoDock Vina [63], where it was also used for optimization and calculation of visualization AutoDock Tools [64], Avogadro [65], and the viewer Discovery Studio [66].

\subsubsection{2. $C A L B$.}

The obtaining of lipase B from Candida antarctica was made in the Protein Data Bank (https://www.rcsb.org/structure/1TCA) repository, where it was deposited with the code 1TCA, which was generated from X-ray diffraction, with a resolution of $1.55 \AA$, R-Value Free: 0.157, Space Group: P 2121 21, with a unit cell with $\mathrm{a}=62.1 \AA$, b $=46.7 \AA, \mathrm{c}=91.1 \AA, \alpha=$ $90^{\circ}, \beta=90^{\circ}, \gamma=90^{\circ}$, being classified as hydrolase enzyme, organism: Moesziomyces antarcticus, consisting of 1 chain (A) [67].

\subsubsection{AChE.}

The enzyme of acetylcholinesterase was also made in the Protein Data Bank (https://www.rcsb.org/structure/4EY6) repository, where it was deposited with the code 4EY6, which was generated from X-ray diffraction, with a resolution of $2.4 \AA$, R-Value Free: 0.206 , Space Group: $\mathrm{P} 61$ with the unit cell with $\mathrm{a}=104.975 \AA, \mathrm{b}=104.975 \AA, \mathrm{c}=323.4 \AA, \alpha=90^{\circ}$, $\beta=90^{\circ}, \gamma=120^{\circ}$, being classified as hydrolase enzyme, organism: Homo sapiens, expressed in Homo sapiens, consisting of 2 chains (A, B) [68]. 
2.9.2. Obtaining the bixin ligand and its derivatives.

The Z,E-bixin ligand was obtained from the ZINC15 (https://zinc15.docking.org/substances/ZINC000004097700/) repository. It was deposited with the code ZINC4097700. The other ligands: bixyl methanoate, bixyl ethanolate, bixyl propanoate, and bixyl butanoate, were constructed in Chem3D software [69, 70].

\subsubsection{Optimization of structures.}

The functions used in determining molecular structures' energy are predominantly based on two theoretical approximations: the classical approximation, which includes the methods of molecular mechanics and molecular dynamics, and the quantum approximation, which provides for the ab initio and semiempirical methods [71]. Structural optimization and electronic characterization of the molecule, it was performed using the molecular mechanics method. This method is used to optimize the geometry of structures because it is helpful to simulate large systems up to thousands of atoms and calculate various thermodynamic and kinetic properties. The results will be the values of the total energies. These results will be analyzed to propose which structure is the most stable [72]. All optimization calculations were performed in the Software Avogadro®, a software that allows performing theoretical calculations (optimization of geometry, energy, and properties) at the level of theory MM, EHT, AM1 / PM3, and MNDO / ZINDO [65, 73, 74].

\subsubsection{Molecular docking.}

Molecular fixation of the bixin ligand and its derivatives to CALB lipase receptors, to verify the catalytic triad of the biocatalytic process, and AChE, to show evidence of inhibition, were performed using the AutoDock Tools graphical interface (4.2.6) that serves AutoDock Vina (1.1.2 ) [64, 75], parameterized with the grid value box according to the natives found in the protein in its co-crystallized form by x-ray diffraction. The two-dimensional images of the interactions and three-dimensional visualization of the complex formed were generated using Discovery Studio 2020 [76].

\section{Results and Discussion}

\subsection{Extraction of material.}

About $0.1 \mathrm{~g}$ of material was obtained after rota-evaporation. The total extraction yield was $5.36 \%$.

\subsection{Yielded of bioesters.}

The equation shown in the methodology was used for the percentage of yield of products resulting from biocatalysis, as shown in Table 1. Thus, the following yields were obtained: bixyl methanoate $23.8 \%$, bixyl ethanoate $13.3 \%$, bixyl propanoate $7.3 \%$, and bixyl butanoate $3.2 \%$. As it was observed, the product that obtained the best yield was bioesterification with methanol, which demonstrates that the larger the chain is its mass bioconversion [77]. 
Table 1. Yield of bioderivatives.

\begin{tabular}{l|c} 
Compound & Mass bioconversion (\%) \\
\hline Bixyl methanoate & $23.8 \%$ \\
\hline Bixyl etanoate & $13.3 \%$ \\
\hline Bixyl propanoate & $7.3 \%$ \\
\hline Bixyl butanoate & $3.2 \%$
\end{tabular}

\subsection{Characterization by FTIR spectroscopy.}

An analysis was performed by infrared spectrometry with Fourier transform to characterize bixin and its derivatives (Fig. 2). These vibrational modes presented are compatible with carotenoids.

The infrared spectrum of the bioproducts showed bands ranging from $3402 \mathrm{~cm}^{-1}$ to 3429 $\mathrm{cm}^{-1}$ related to the vibration of axial O-H deformation of the acid carboxyl group.

The methyl group's asymmetric axial deformation was reported in the region with peaks around 2360-2368 $\mathrm{cm}^{-1}$. Bands around 2941 to $2920 \mathrm{~cm}^{-1}$ were related to axial deformation of the olefinic $\mathrm{C}-\mathrm{H}$ bond. The band around $1710-1730 \mathrm{~cm}^{-1}$ is due to the axial deformation vibration of group $\mathrm{C}=\mathrm{O}$. The band around $1616-1620 \mathrm{~cm}^{-1}$ was related to axial deformation of the $\mathrm{C}=\mathrm{C}$ bond.

The bands between $1377-1388 \mathrm{~cm}^{-1}$ represent methyl group deformation, and between $1438 \mathrm{~cm}^{-1}$ and $1456 \mathrm{~cm}^{-1}$, the angular deformation of the $\mathrm{O}-\mathrm{H}$ bond of the carboxylic acid group. The bands between $1264-1288 \mathrm{~cm}^{-1}$ refer to the axial deformation of the C-O bond of carboxylic acids. Axial deformation vibration of the $\mathrm{C}-\mathrm{O}$ bond is also represented in this spectrum in $1159-1162 \mathrm{~cm}^{-1}$. The band at $1039-1031 \mathrm{~cm}^{-1}$ is due to the axial deformation vibration of the $\mathrm{C}-\mathrm{O}$ bond in the esters' $\mathrm{O}-\mathrm{C}-\mathrm{C}$ arrangement derived from primary water sources.

Finally, the vibrational modes of angular deformation outside the plane of the olefinic $\mathrm{C}-\mathrm{H}$ bond appeared at $713 \mathrm{~cm}^{-1}$ due to the absorption of radiation from the double arrangement in the cis geometry; the other vibrations around 580,555 , and $553 \mathrm{~cm}^{-1}$ refer to the different vibrational modes of the $\mathrm{C}-\mathrm{H}$ bond of an olefinic nature [78].

\subsection{Antioxidant activity.}

In the antioxidant activity by DPPH free radical sequestration, a relationship between activity-concentration was observed in each sample, as shown in Table 2 . Where it was possible to visualize the percentages of antioxidant potential with a variation of 71.7-3.6\% for bixyl butanoate, with $\mathrm{IC}_{50}$ of $0.021 \mathrm{mg} / \mathrm{mL}$ and for the ester that presented the lowest activity, bixyl ethanoate, with variation between $33.2-0.6 \%$, with $\mathrm{IC}_{50}$ of $0.05 \mathrm{mg} / \mathrm{mL}$. For the other esters, a structural relationship was not observed based on their activity, as shown by bixin itself, bixyl methanoate, and bixyl propanoate, which had the values of IC $_{50}$ very close to $0.0227 \mathrm{mg} / \mathrm{mL}$, $0.0272 \mathrm{mg} / \mathrm{ml}$, and $0.0276 \mathrm{mg} / \mathrm{mL}$. Previous studies have shown that the larger the alkyd chain in phenolic compounds, the greater its molecular stability, due to its inductive donor effect of the alkyl groups, in the case of bixyl butanoate, which may have influenced the results presented [79]. 


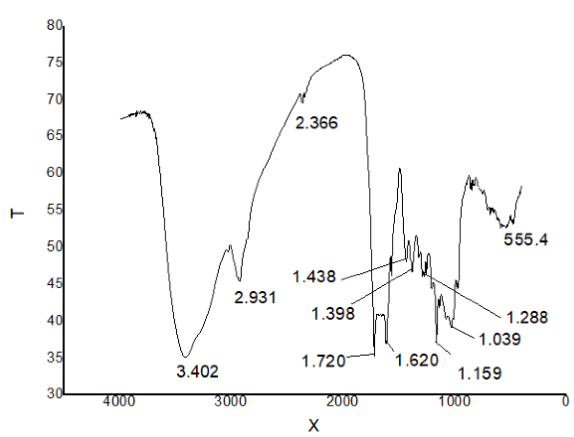

Bixyl methanoate

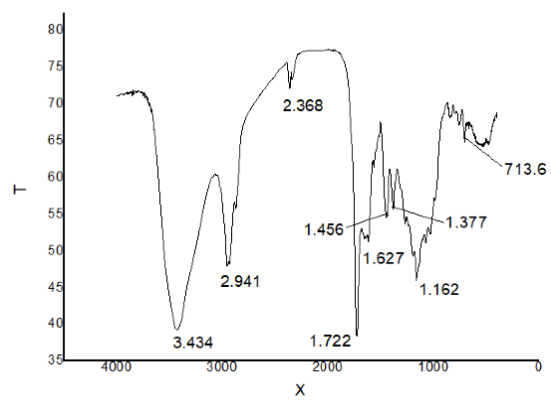

Bixyl propanoate

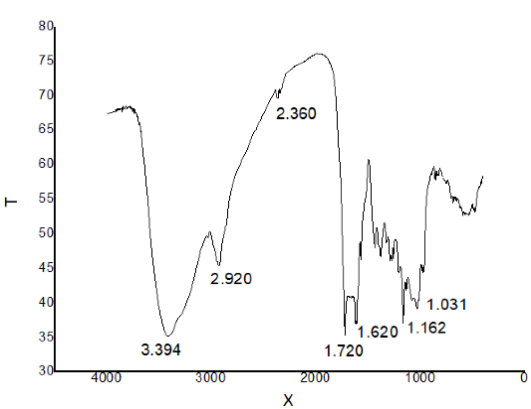

Bixyl ethanoate

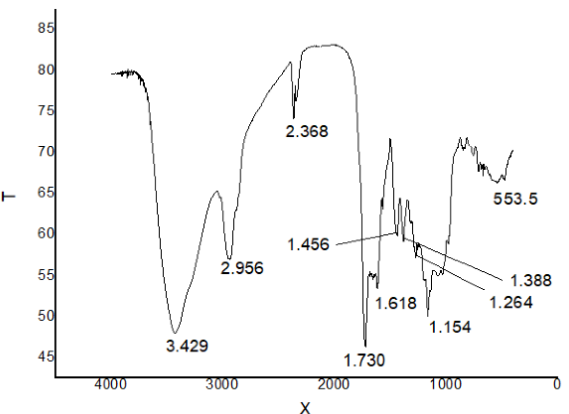

Bixyl butanoate

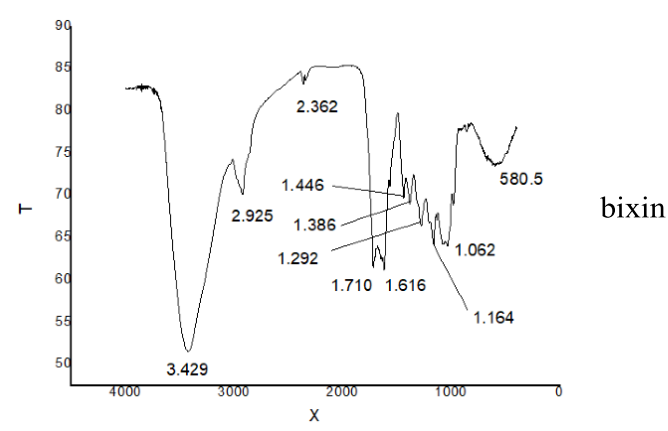

Figure 2. FTIR spectroscopy of bixin and its bioderivatives.

Table 2. Antioxidant activity results.

\begin{tabular}{|c|c|c|c|c|c|c|c|c|c|c|}
\hline \multirow{2}{*}{$\begin{array}{l}\text { Conc } \\
(\mathrm{mg} / \mathrm{mL})\end{array}$} & \multicolumn{2}{|l|}{ bixin } & \multicolumn{2}{|c|}{ Bixyl methanoate } & \multicolumn{2}{|c|}{ Bixyl ethanoate } & \multicolumn{2}{|c|}{ Bixyl propanoate } & \multicolumn{2}{|c|}{ Bixyl butanoate } \\
\hline & $\%$ & Abs & $\%$ & Abs & $\%$ & Abs & $\%$ & Abs & $\%$ & Abs \\
\hline 0.03125 & 54.649 & 0.411 & 57.9 & 0.093 & 33.2 & 0.184 & 62.3 & 0.083 & 71.7 & 0.062 \\
\hline 0.015625 & 51.782 & 0.437 & 28.3 & 0.158 & 20.8 & 0.219 & 14.5 & 0.188 & 46.2 & 0.118 \\
\hline 0.007813 & 32.635 & 0.440 & 8.2 & 0.202 & 19.8 & 0.221 & 10.0 & 0.198 & 7.1 & 0.204 \\
\hline 0.003906 & 21.389 & 0.460 & 2.6 & 0.214 & 18.1 & 0.226 & 7.9 & 0.203 & 6.2 & 0.206 \\
\hline 0.001953 & 16.097 & 0.590 & 1.7 & 0.216 & 0.6 & 0.274 & 0.9 & 0.218 & 3.6 & 0.212 \\
\hline $\mathrm{IC}_{50}$ & \multicolumn{2}{|c|}{0.022709} & \multicolumn{2}{|c|}{0.027258} & \multicolumn{2}{|c|}{0.050238} & \multicolumn{2}{|c|}{0.027669} & \multicolumn{2}{|c|}{0.02134} \\
\hline
\end{tabular}

3.5. Ecotoxicity activity.

After 24 and 48 hours, the percentage of mortality of Artemia salina larvae was calculated in concentrations of bioproduct samples and lethal dose $\left(\mathrm{LD}_{50}\right)$ using probit log-dose regression [80] in triplicate. For the toxicity scale, extremely toxic samples are considered when their lethal dose of $50 \%\left(\mathrm{LD}_{50}\right)$ has values below $1 \mathrm{ppm}$; highly toxic when the value of $\mathrm{LD}_{50}$ is between 1 to $50 \mathrm{ppm}$; moderately toxic when the value of $\mathrm{LD}_{50}$ passes between 50 and 500 ; slightly toxic when the value of $\mathrm{LD}_{50}$ is between 500 and $5000 \mathrm{ppm}$; and practically nontoxic when the $\mathrm{LD}_{50}$ is above $5000 \mathrm{ppm}[62]$. 
Initially, the lethal dose $\left(\mathrm{LD}_{50}\right)$ data for bixin after the first 24 hours were $250.377 \mathrm{ppm}$, and after 48 hours, it presented 500.208 ppm, considering them as moderately toxic. For bixyl propanoate, an $\mathrm{LD}_{50}$ of $470.40 \mathrm{ppm}$ was obtained in the first $24 \mathrm{~h}$ and then $952.30 \mathrm{ppm}$ for $48 \mathrm{~h}$ later, which was slightly toxic. Both bixyl butanoate and bixyl ethanoate got a lethal dose in the first 24 hours of $2,266.10 \mathrm{ppm} / 1,865.20$, up to $48 \mathrm{~h}$ with $4,855.60 \mathrm{ppm} / 3,680.30 \mathrm{ppm}$, and was also slightly toxic. Only bixyl methanoate was somewhat toxic in the $24 \mathrm{~h}$ with $\mathrm{LD}_{50}$ of 3,177.40 ppm and after $48 \mathrm{~h}$ with an $\mathrm{LD}_{50}$ of $6,828.50 \mathrm{ppm}$, considered non-toxic. Despite the experimentally presented moderately toxicity results, previous reports on liver and kidney samples from rats demonstrated bixin as non-toxic [80]. Therefore, no clinical, behavioral, necroscopic, and histological alterations were observed. Under the study conditions, bixin produced no toxic effects on exposed animals [81]. These results are presented in Table 3 and Fig. 3.

Table 3. Results of ecotoxicity of bioproducts in 24 and $48 \mathrm{~h}$.

\begin{tabular}{|c|c|c|c|}
\hline \multirow[t]{2}{*}{ Esters } & \multicolumn{2}{|c|}{ LD $_{50}(\mathbf{p p m})$} & \multirow[t]{2}{*}{ Ecotoxicity } \\
\hline & $24 h$ & $48 \mathrm{~h}$ & \\
\hline Bixyl methanoate & $3,177.40$ & $6,828.50$ & slightly toxic/non-toxic \\
\hline Bixyl butanoate & $2,266.10$ & $4,855.60$ & slightly toxic \\
\hline Bixyl ethanoate & $1,865.20$ & $3,680.30$ & slightly toxic \\
\hline Bixyl propanoate & 470.40 & 952.30 & slightly toxic \\
\hline Bixin & 250.377 & 500.208 & moderately toxic \\
\hline
\end{tabular}

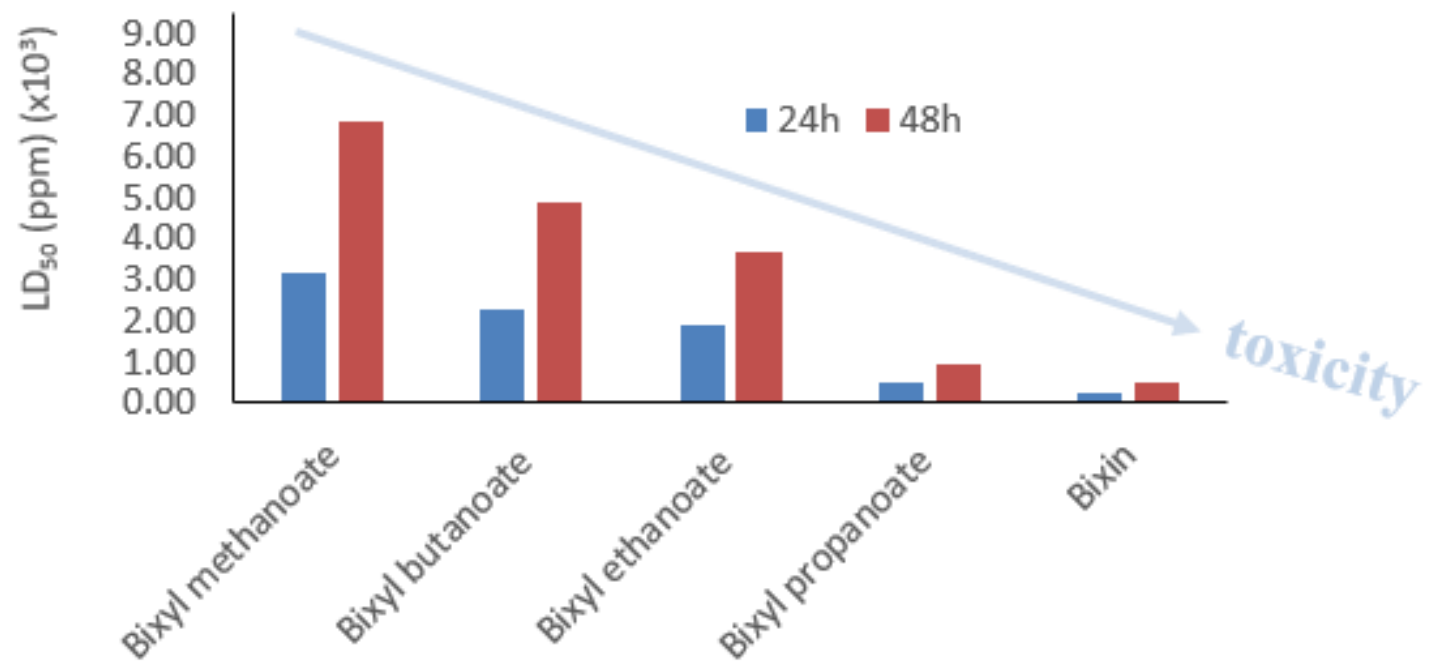

Figure 3. Ecotoxicity of bixin and its derivatives.

3.6. In vitro study.

3.6.1. Result of bioesterification analysis by molecular docking of bixin with lipase (CALB).

Based on the literature [82] and with some adaptations [83], this molecular coupling simulation study was used to elucidate the transesterification interactions between bixin and lipase in the formation of four esters.

The coupling molecule by Autodock vina made it possible to list the ligands' affinity and RMSD energies, as shown in Table 4.

Table 4. Result of molecular coupling with its energy and RMSD.

\begin{tabular}{l|c|c} 
Carotenoid & Energy affinity (Kcal/mol) & RMSD \\
\hline bixin & -5.4 & 2.2
\end{tabular}


Generally, the catalytic triad of a lipase consists of Ser-His-Asp. The simulation suggested that Serina 105, Histidine 224, and Aspartic Acid 187 are typically protected by a hydrophobic helical cap called "lid" [84, 85].

This enzyme presented a much-needed residue in the hydrophilic interaction, effectively activating esterification reactions for ester production, Thr 158 [86]. In addition to this residue, a hydrophobic interaction of Leucine 278 was observed [87].

The reactions of bixin ester production occurred with the formation of bixyl alkyloates, as shown in Fig. 4.

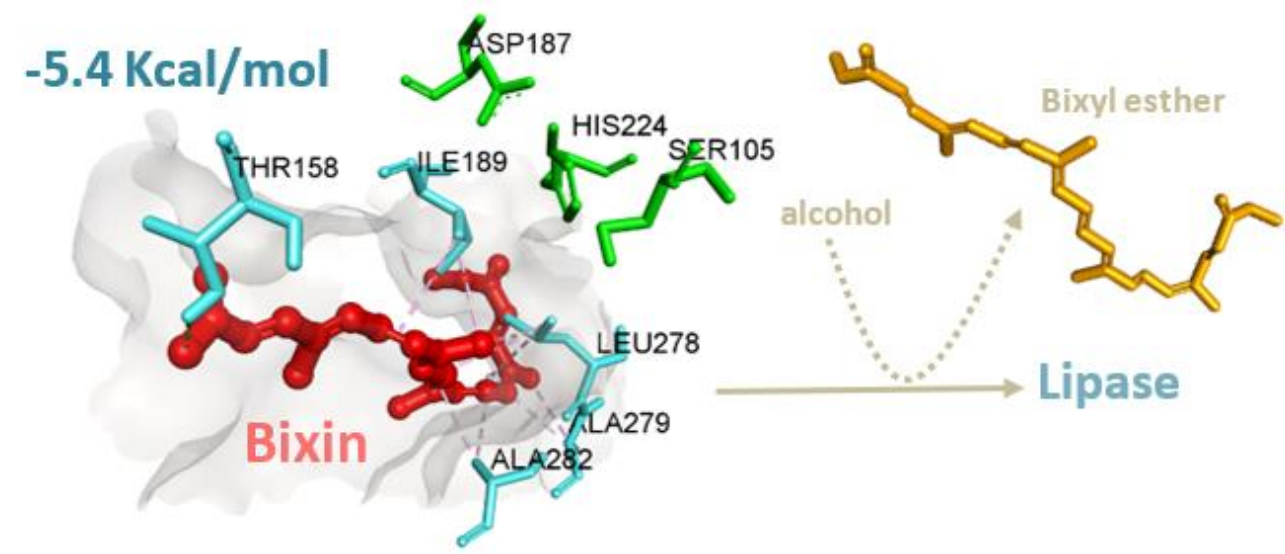

Figure 4. The mechanism by docking bixin (red) with lipase amino acid residues (blue) and catalytic triad (green) visualized by Discovery Studio 2020 [76].

The simulation was chosen to perform molecular anchoring blindly [88], where the grid was established throughout the enzymatic region. Standard practice is when one does not have a native file of the co-crystallized file obtained by X-ray diffraction. It is possible to check-in Fig. 5 the bixin with their respective amino acid residues of lipase. There is a hydrophilic approach to the Thr 158 residue making a hydrogen bond $2.8 \AA$ away. Also, four approaches of hydrophobic nature of the alkyl type were observed: one in the residue Ileu 189 in two regions of bixin, with 4.5 and the other with $3.9 \AA$ distance, in Ala279 with $5.1 \AA$, Ala282 with $2.8 \AA$, and in Leu278, in three regions with the spread between $2-3 \AA$.

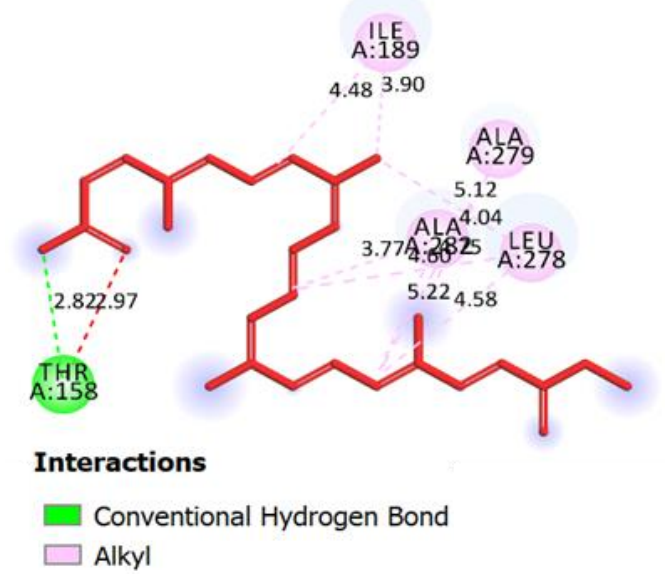

Figure 5. 2D interactions of bixin with CALB with proper distances in $\AA$ at Discovery Studio 2020 [76].

3.6.2. Result of bixin and its derivates simulation by molecular docking against the AChE enzyme.

Based on the simulation of bixin and the other bioesters, with AutoDock Vina [63], against the enzyme $\mathrm{AChE}$ and using galantamine as a comparison, it was possible to verify that 
bixin presented better receptor-binder interaction on its bioderivatives (Table 5). With a minimal difference in energy affinity level $(\mathrm{kcal} / \mathrm{mol})$ and its mean square deviation (RMSD) ratio, excluding only bixyl butanoate that had lower stability with affinity energy of -6.0 $\mathrm{kcal} / \mathrm{mol}$, compared to the others, as shown in Table 6.

Table 5. Comparison of interactions of ache enzyme residues between galantamine and bixin.

\begin{tabular}{l|l|l}
\multirow{2}{*}{ Residues } & Distance $(\AA)$ \\
\cline { 2 - 3 } & galantamine & bixin \\
\hline Trp86 & $4.32 / 5.24$ & $3.50 / 5.48$ \\
\hline Gly121 & 4.13 & 3.61 \\
\hline Tyr124 & 3.46 & 3.76 \\
\hline Tyr337 & 5.33 & $5.49 / 5.20$ \\
\hline Phe338 & 4.82 & 5.11 \\
\hline His447 & $3.06 / 5.15$ & 5.49
\end{tabular}

Table 6. Data from the simulation of bixin and bioderived esters.

\begin{tabular}{l|l|c}
$\mathbf{k c a l} / \mathbf{m o l}$ & Esters & RMSD \\
\hline-9.1 & Bixin & 1.6 \\
\hline-8.7 & Bixyl ethanoate & 2.3 \\
\hline-8.6 & Bixyl methanoate & 2.4 \\
\hline-8.3 & Bixyl propanoate & 1.7 \\
\hline-6.0 & Bixyl butanoate & 2.9
\end{tabular}

This behavior can be caused by a four-carbon alkyl chain, which tends to increase the lipophilicity of the bioester and decrease its interaction with the enzyme.

In Figure 6. It is shown that bixin (red) is linked in the same region of galantamine (orange) ligand, which is currently one of the drugs widely used to inhibit acetylcholine [89]. It can also verify two hydrophilic interactions in Tyr124 and Gly121 residues, with hydrogen bonding by carbonyl. In these four hydrophobic interactions, two Pi-alkyl types are perceived in Tyr337 residue, a significant segment, the His447 and Phe338 residues, responsible for inhibiting the enzyme $[89,90]$, and one of the Pi-sigma types, in the residue Trp86.

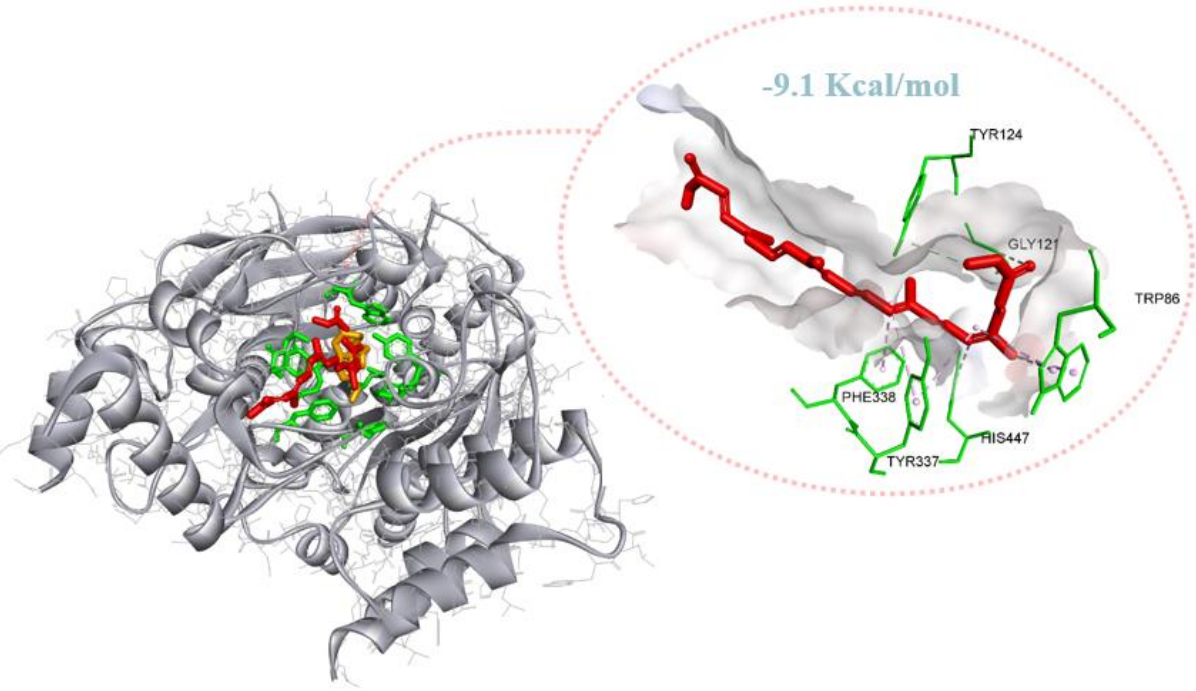

Figure 6. Bixin and derivatives (red) with $\mathrm{AChE}$ and its amino acid residues (green) and the native used binder Galantamine® (orange), visualized by Discovery Studio 2020 [76].

\section{Conclusions}

After carotenoid (bixin) has been extracted from the annatto seed employing a binary mixture of organic solvents, it was possible to perform an enzymatic catalysis reaction to obtain the bioderivatives: bixyl butanoate (3.2\%), bixyl propanoate (7.3), bixyl ethanoate (13.3) and 
bixyl methanoate (23.8), proving the versatility of CALB lipase despite low mass conversions. After obtaining these bioproducts, it was verified that its antioxidant and ecotoxicity levels, where bixyl butanoate presented a higher antioxidant capacity, with $71.7 \%$ in its highest concentration lower level of ecotoxicity, with slightly toxic classification. Through molecular anchorage simulation with the acetylcholinesterase enzyme, bixin showed the best receptorbinding interaction compared to its bioderivatives and the positive commercially used pattern, galantamine, with affinity energy $-9.1 \mathrm{kcal} / \mathrm{mol}$. This study contributes to the search for new compounds in the face of Alzheimer's disease.

\section{Funding}

This research received no external funding.

\section{Acknowledgments}

The authors would like to thank to the Brazilian Agencies: Fundação Cearense de Apoio ao Desenvolvimento Científico e Tecnológico (FUNCAP). Conselho Nacional de Desenvolvimento Científico e Tecnológico (CNPq) and Coordenação de Aperfeiçoamento de Ensino Superior (CAPES) for fellowships and financial supports.

\section{Conflicts of Interest}

The authors declare no conflict of interest.

\section{References}

1. Carvalho, P.R.N.; da Silva, M.G.; Fabri, E.G.; Tavares, P.E.da R.; Martins, A.L.M.; Spatti, L.R. Concentração de Bixina e Lipídios Em Sementes de Urucum Da Coleção Do Instituto Agronômico(IAC). Bragantia 2010, 69, 519-524, https://doi.org/10.1590/s0006-87052010000300002.

2. Franco, C.F.O.; Silva, F.C.P.; Cazé Filho, J.; Barreiro Neto, M.; São José, A.R.; Rebouças, T.N.H. Fontinélli, I.S.C. Etnobotânica e Taxonomia do Urucuzeiro http://www.infobibos.com/Artigos/2008_1/UrucumTaxon/index.htm (accessed Jun 14, 2013).

3. Villacrés-Vallejo, J.; Aranda-Ventura, J.; Wallis, A.; Cagle, R.; Handy, S.M.; Davis, J.; Reed, E.; Zhang, S.; Strain, E.; Pava-Ripoll, M.; Erickson, D.; Ramachandran, P.; Ottesen, A. Using full chloroplast genomes of 'red' and 'yellow' Bixa orellana (achiote) for kmer based identification and phylogenetic inference. BMC Genomics 2020, 21, https://doi.org/10.1186/s12864-020-06916-0.

4. Pedrosa, J.P.; Cirne, L.E.d.M.R.; Neto, M.; de. Teores, J.M. Bixina e Proteína Em Sementes de Urucum Em Função Do Tipo e Do Período de Armazenagem. Rev. Bras. Eng. Agrícola e Ambient. 1999, 3, 121-123, https://doi.org/10.1590/1807-1929/agriambi.v3n1p121-123.

5. Liang, M.-H.; He, Y.-J.; Liu, D.-M.; Jiang, J.-G. Regulation of carotenoid degradation and production of apocarotenoids in natural and engineered organisms. Critical Reviews in Biotechnology 2021, 41, 513-534, https://doi.org/10.1080/07388551.2021.1873242.

6. Field, J.A.; de Jong, E.; Feijoo Costa, G.; de Bont, J.A. Biodegradation of polycyclic aromatic hydrocarbons by new isolates of white rot fungi. Applied and Environmental Microbiology 1992, 58, 2219-2226, https://doi.org/10.1128/aem.58.7.2219-2226.1992.

7. Guajardo, N.; Domínguez de María, P. Assessing biocatalysis using dihydrolevoglucosenone $\left(\mathrm{Cyrene} \mathrm{T}^{\mathrm{TM}}\right)$ as versatile bio-based (co)solvent. Molecular Catalysis 2020, 485, https://doi.org/10.1016/j.mcat.2020.110813.

8. Faber, K. Biotransformations in Organic Chemistry. 2011; https://doi.org/10.1007/978-3-642-17393-6.

9. Silverman, R.B. The Organic Chemistry of Enzyme-Catalyzed Reactions. Academic Press: London, 2002.

10. Desa, A.M.; Mohd, M.H.; Uzir, M.H. Bifurcation Analysis of an Exothermic Biocatalytic Reaction System. Pertanika J. Sci. Technol. 2021, 29, 165-180, https://doi.org/10.47836/pjst.29.1.09.

11. Gupta, R.; Gupta, N.; Rathi, P. Bacterial Lipases: An Overview of Production, Purification and Biochemical Properties. Appl. Microbiol. Biotechnol. 2004, 64, 763-781, https://doi.org/10.1007/s00253-004-1568-8.

12. Megawati, M.; Artanti, N.; Mulyani, H.; Darmawan, A.; Syahrian, H.; Lotulung, P.D.N.; Supriadi, E.; Widiyarti, G.; Dewi, R.T.; Meilawati, L.; Ernawati, T.; Dewijanti, I.D.; Minarti, M. In Vitro Lipase Enzyme Inhibitory Activities of Green Tea and Other Herbs. J. Gizi Indones. (The Indones. J. Nutr. 2020, 9, https://doi.org/10.14710/jgi.9.1.48-52. 
13. Ramos, L.P.; Da Silva, F.R.; Mangrich, A.S.; Cordeiro, C.S. Tecnologias de Produção de Biodiesel. Rev. Virtual Quim. 2011, 3, 385-405.

14. Soares, A.d.S.; Leite Júnior, B.R.de C.; Tribst, A.A.L.; Augusto, P.E.D.; Ramos, A.M. Effect of Ultrasound on Goat Cream Hydrolysis by Lipase: Evaluation on Enzyme, Substrate and Assisted Reaction. LWT 2020, 130. https://doi.org/10.1016/j.lwt.2020.109636.

15. Yao, Y.; Wang, M.; Liu, Y.; Han, L.; Liu, X. Insights into the Improvement of the Enzymatic Hydrolysis of Bovine Bone Protein Using Lipase Pretreatment. Food Chem. 2020, 302, https://doi.org/10.1016/j.foodchem.2019.125199.

16. Zieniuk, B.; Fabiszewska, A.; Białecka-Florjańczyk, E. Screening of Solvents for Favoring Hydrolytic Activity of Candida Antarctica Lipase B. Bioprocess Biosyst. Eng. 2020, 43, 605-613, https://doi.org/10.1007/s00449-019-02252-0.

17. Xu, Y.; Du, W.; Liu, D. Study on the Kinetics of Enzymatic Interesterification of Triglycerides for Biodiesel Production with Methyl Acetate as the Acyl Acceptor. J. Mol. Catal. B Enzym. 2005, 32, 241-245, https://doi.org/10.1016/j.molcatb.2004.12.013.

18. Breithaupt, D.E. Enzymatic Hydrolysis of Carotenoid Fatty Acid Esters of Red Pepper (Capsicum Annuum L.) by a Lipase from Candida Rugosa. Zeitschrift fur Naturforsch. - Sect. C J. Biosci. 2000, 55, 971-975, https://doi.org/10.1515/znc-2000-11-1220.

19. Zorn, H.; Breithaupt, D. E.; Takenberg, M.; Schwack, W.; Berger, R.G. Enzymatic Hydrolysis of Carotenoid Esters of Marigold Flowers (Tagetes Erecta L.) and Red Paprika (Capsicum Annuum L.) by Commercial Lipases and Pleurotus Sapidus Extracellular Lipase. Enzyme Microb. Technol. 2003, 32, 623-628, https://doi.org/10.1016/S0141-0229(03)00020-6.

20. Modi, M.K.; Reddy, J.R.C.; Rao, B.V.S.K.; Prasad, R.B.N. Lipase-Mediated Conversion of Vegetable Oils into Biodiesel Using Ethyl Acetate as Acyl Acceptor. Bioresour. Technol. 2007, 98, 1260-1264, https://doi.org/10.1016/j.biortech.2006.05.006.

21. Ketut, C.N.I.; Yusvardi, Y.; Muhamad, K.F. Myristic Acid as Phase Change Material (PCM) for Increased Productivity of Solar Distillation Plant. International Review of Applied Sciences and Engineering. 2020, 226-231, https://doi.org/10.1556/1848.2020.00077.

22. Lima, L.R.P.; Oliveira, T.T.d.; Nagem, T.J. Efeitos Do Flavonóide Quercetina e Dos Corantes Bixina e Norbixina Sobre Parâmetros Sanguíneos de Coelhos. Rev. Nutr. 2003, 16, 305-314, https://doi.org/10.1590/s1415-52732003000300008.

23. Vilar, D.d.A.; Vilar, M.S.d.A.; Moura, T.F.A.d.L.e.; Raffin, F.N.; Oliveira, M.R.d.; Franco, C.F.d.O.; de Athayde-Filho, P.F.; Diniz, M.d.F.F.M.; Barbosa-Filho, J.M. Traditional Uses, Chemical Constituents, and Biological Activities of Bixa Orellana L.: A Review. Sci. World J. 2014, 2014, https://doi.org/10.1155/2014/857292.

24. Bandoni, A.L.; Mendiondo, M.E.; Rondina, R.V.D.; Coussio, J.D. Survey of argentine medicinal plants Folklore and phytochemical — Screening. II. Economic Botany 1976, 30, 161-185, https://doi.org/10.1007/BF02862962.

25. Pascoal, K.L.L.; Siqueira, S.M.C.; Alves, D.R.; Morais, S.M.; Melo, R.S.; Amorim, A.F.V.; Fernandes, A.M. Avaliação Da Inibição Da Enzima Acetilcolinesterase Do Carotenoide Bixina Extraído Das Sementes de Urucum. In: Anais do Encontro do Programa de Pós-Graduação em Ciências Farmacêuticas. 2017; pp. 1, https://doi.org/10.17648/ppgcf-2017-66331.

26. Michalea, R.; Stathopoulou, K.; Polychronopoulos, P.; Benaki, D.; Mikros, E.; Aligiannis, N. Efficient Identification of Acetylcholinesterase and Hyaluronidase Inhibitors from Paeonia Parnassica Extracts through a HeteroCovariance Approach. J. Ethnopharmacol. 2020, 257, https://doi.org/10.1016/j.jep.2018.10.008.

27. Fenclová, E.; Albrecht, J.; Harsa, P.; Jirák, R. Risk Factors for Alzheimer's Disease. Ces. a Slov. Psychiatr. 2020, 116, 59-65, https://doi.org/10.15354/si.20.re036.

28. Guo, Z.; Zhang, P.; Luo, Y.; Xie, H. Q.; Chakraborty, S.; Monikh, F. A.; Bu, L.; Liu, Y.; Ma, Y.; Zhang, Z.; Valsami-Jones, E.; Zhao, B.; Lynch, I. Intranasal Exposure to ZnO Nanoparticles Induces Alterations in Cholinergic Neurotransmission in Rat Brain. Nano Today 2020, 35, https://doi.org/10.1016/j.nantod.2020.100977.

29. Sereniki, A.; Vital, M.A.B.F.A Doença de Alzheimer: Aspectos Fisiopatológicos e Farmacológicos. Rev. Psiquiatr. do Rio Gd. do Sul 2008, 30, https://doi.org/10.1590/S0101-81082008000200002.

30. Filho, B.J.M.; Medeiros, K.C.P.; Diniz, M.de F.F.M.; Batista, L.M.; Athayde-Filho, P.F.; Silva, M.S.; Cunha, E.V.L.da; Almeida, J.R.G.S.; Quintans-Júnior, L.J. Natural Products Inhibitors of the Enzyme Acetylcholinesterase. Rev. Bras. Farmacogn. 2006, 16, 258-285, https://doi.org/10.1590/S0102695X2006000200021.

31. Soldan, A.; Gazes, Y.; Stern, Y. Alzheimer's Disease. Elsevier Science Ltd., 2016; https://doi.org/10.1016/B978-0-12-809324-5.06319-7.

32. Forlenza, O.V. Tratamento Farmacológico Da Doença de Alzheimer. Arch. Clin. Psychiatry (São Paulo) 2005, 32, 137-148, https://doi.org/10.1590/S0101-60832005000300006.

33. Nabati, M.; Bodaghi-Namileh, V. Molecular Modeling of 3-(1,3-Dioxoisoindolin-2-Yl)Benzyl Nitrate and Its Molecular Docking Study with Phosphodiesterase-5 (PDE5). Adv. J. Chem. A 2020, 3, 58-69, https://doi.org/10.33945/sami/ajca.2020.1.7. 
34. Salvadori, A.; Del Frate, G.; Pagliai, M.; Mancini, G.; Barone, V. Immersive Virtual Reality in Computational Chemistry: Applications to the Analysis of QM and MM Data. Int. J. Quantum Chem. 2016, 116, 1731-1746, https://doi.org/10.1002/qua.25207.

35. Oliveira, A.M. Introdução a Modelagem Molecular Para Química, Engenharia e Biomédicas: Fundamentos e Exercícios. Appis: Curitiba, 2018.

36. Eren, D.; Yalçin, I. The Aim of Implementation of the Molecular Mechanic and the Molecular Dynamic Methods in Rational Drug Design. Ankara Univ. Eczac. Fak. Derg. 2020, 44, 334-355.

37. Godói, I.; Lima, W.; Comar, M.; Alves, R.; Ferreira, M.; Kong, D.-X.; Taranto, A.G. Docking and QM/MM Studies of NS2B-NS3pro Inhibitors: A Molecular Target against the Dengue Virus. J. Braz. Chem. Soc. 2017, 28, 895-906, https://doi.org/10.21577/0103-5053.20160242.

38. Arroio, A.; Honório, K.M.; Weber, K.C.; Homem-De-Mello, P.; Da Silva, A.B F.O. Ensino de Química Quântica e o Computador Na Perspectiva de Projetos The Teaching of Quantum Chemistry and the Computer from the Perspective Projects. Quim. Nov. 2005, 28, 360-363.

39. Mazurek, A.H.; Szeleszczuk, Ł.; Simonson, T.; Pisklak, D. M. Application of Various Molecular Modelling Methods in the Study of Estrogens and Xenoestrogens. Int. J. Mol. Sci. 2020, 21, 1-31, https://doi.org/10.3390/ijms21176411.

40. Vallury, H.J.; Jones, M.A.; Hill, C.D.; Hollenberg, L.C.L. Quantum Computed Moments Correction to Variational Estimates. Quantum 2020, 4, 1-11, https://doi.org/10.22331/Q-2020-12-15-373.

41. Liao, C.; Sitzmann, M.; Pugliese, A.; Nicklaus, M.C. Software and Resources for Computational Medicinal Chemistry. Future Med. Chem. 2011, 3, 1057-1085, https://doi.org/10.4155/fmc.11.63.

42. Matter, H. Computational Medicinal Chemistry for Drug Discovery. Drug Discov. Today 2004, 9, 350, https://doi.org/10.1016/S1359-6446(04)03071-5.

43. Bultinck, P.; Winter, H. De; Langenaeker, W.; Tollenare, J. P. Computational Medicinal Chemistry for Drug Discovery. CRC Press, 2003.

44. Duarte, H.A. Carga Nuclear Efetiva e Sua Conseqüência Para a Compreensão Da Estrutura Eletrônica Dos Átomos. Química Nov. na Esc. 2003, 17, 22-26.

45. Leal, R.C.; Moita Neto, J.M.; Lima, F.das C.A.; Feitosa, C.M. A Química Quântica Na Compreensão de Teorias de Química Orgânica. Quim. Nova 2010, 33, 1211-1211, https://doi.org/10.1590/s010040422010000500037.

46. Leach, A.R.; Gillet, V.J. An Introduction to Chemoinformatics. Springer Netherlands, 2007; https://doi.org/10.1007/978-1-4020-6291-9.

47. Ferreira, L.G.; Dos Santos, R.N.; Oliva, G.; Andricopulo, A.D. Molecular Docking and Structure-Based Drug Design Strategies. Molecules 2015, 20, 13384-13421, https://doi.org/10.3390/molecules200713384.

48. Hassan, M.; Ashraf, Z.; Abbas, Q.; Raza, H.; Seo, S.Y. Exploration of Novel Human Tyrosinase Inhibitors by Molecular Modeling, Docking and Simulation Studies. Interdiscip. Sci. Comput. Life Sci. 2018, 10, 6880, https://doi.org/10.1007/s12539-016-0171-x.

49. Koola, M.M. Galantamine-Memantine Combination in the Treatment of Alzheimer's Disease and Beyond. Psychiatry Res. 2020, 293, https://doi.org/10.1016/j.psychres.2020.113409.

50. Leijenaar, J.F.; Groeneveld, G.J.; Klaassen, E.S.; Leeuwis, A.E.; Scheltens, P.; Weinstein, H.C.; van Gerven, J.M.A.; Barkhof, F.; van der Flier, W.M.; Prins, N.D. Methylphenidate and galantamine in patients with vascular cognitive impairment-the proof-of-principle study STREAM-VCI. Alzheimer's Research \& Therapy 2020, 12, https://doi.org/10.1186/s13195-019-0567-z.

51. Naguib, S.; Bernardo-Colón, A.; Cencer, C.; Gandra, N.; Rex, T.S. Galantamine protects against synaptic, axonal, and vision deficits in experimental neurotrauma. Neurobiology of Disease 2020, 134, https://doi.org/10.1016/j.nbd.2019.104695.

52. Ramalho, H.F.; Suarez, P.A.Z. A Quimica Dos Óleos e Gorduras e Seus Processos de Extração e Refino. Rev. Virtual Quim. 2013, 5, 2-15.

53. Aarthy, M.; Saravanan, P.; Gowthaman, M.K.; Rose, C.; Kamini, N.R. Enzymatic transesterification for production of biodiesel using yeast lipases: An overview. Chemical Engineering Research and Design 2014, 92, 1591-1601, https://doi.org/10.1016/j.cherd.2014.04.008.

54. Monteiro, R.R.C. Produção de Biodiesel: Óleo Residual e Biocatalizador Enzimático Suportado Em Nanoparticulas Magnéticas. In: Experiências em Ensino, Pesquisa e Extensão na Unilab: Caminhos e Perspectivas. Imprece: Fortaleza, 2018.

55. Gomes, P.H.L. Avaliação de Um Coquetel Enzimático de Lipases Na Síntese de Oleato de Etila. In: Experiências em Ensino, Pesquisa e Extensão na Unilab: Caminhos e Perspectivas. Imprece: Fortaleza, 2018.

56. Rezende, G.B.; Fernandes, D.M.; Ferreira, D.C.; Gonçalves, J.C.d.S.I. Venturi: Hydrodynamic Cavitation Device to Accelerate Biodiesel Synthesis. Eng. Sanit. e Ambient. 2021, 26, 105-112, https://doi.org/10.1590/s1413-415220190177.

57. Colares, R.P.; de Lemos, T.L.G.; Monte, F.J.Q.; Alcocer, J.C.A.; de Oliveira, M.M.; Fonseca, A.M. The effect of chlorophyll degradation (ECD) as qualitative antioxidant assay in Eruca sativa leaves. Revista Virtual de Química 2017, 9, 2642-2649, https://doi.org/10.21577/1984-6835.20170154. 
58. Chen, X.; Liang, L.; Han, C. Borate suppresses the scavenging activity of gallic acid and plant polyphenol extracts on DPPH radical: A potential interference to DPPH assay. LWT 2020, 131, https://doi.org/10.1016/j.lwt.2020.109769.

59. Tepe, B.; Daferera, D.; Sokmen, A.; Sokmen, M.; Polissiou, M. Antimicrobial and antioxidant activities of the essential oil and various extracts of Salvia tomentosa Miller (Lamiaceae). Food Chemistry 2005, 90, 333340, https://doi.org/10.1016/j.foodchem.2003.09.013.

60. Meyer, B.N.; Ferrigni, N.R.; Putnam, J.E.; Jacobsen, L.B.; Nichols, D.E.; McLaughlin, J.L. Brine shrimp: a convenient general bioassay for active plant constituents. Planta Med 1982, 45, 31-34, https://doi.org/10.1055/s-2007-971236.

61. Abu Ahmed, A.M.; Sharmen, F.; Mannan, A.; Rahman, M.A. Phytochemical, Analgesic, Antibacterial, and Cytotoxic Effects of Alpinia Nigra (Gaertn.) Burtt Leaf Extract. J. Tradit. Complement. Med. 2015, 5, 248252, https://doi.org/10.1016/j.jtcme.2014.11.012.

62. do Amarante, C.B.; Müller, A.H.; Póvoa, M.M.; Dolabela, M.F. Estudo Fitoquímico Biomonitorado Pelos Ensaios de Toxicidade Frente à Artemia Salina e de Atividade Antiplasmódica Do Caule de Aninga (Montrichardia Linifera). Acta Amaz. 2011, 41, 431-434, https://doi.org/10.1590/S004459672011000300015.

63. Trott, O.; Olson, A.J. AutoDock Vina: Improving the Speed and Accuracy of Docking with a New Scoring Function, Efficient Optimization, and Multithreading. J. Comput. Chem. 2009, https://doi.org/10.1002/jcc.21334.

64. Morris, G.M.; Ruth, H.; Lindstrom, W.; Sanner, M.F.; Belew, R.K.; Goodsell, D.S.; Olson, A.J. Software News and Updates AutoDock4 and AutoDockTools4: Automated Docking with Selective Receptor Flexibility. J. Comput. Chem. 2009, 30, 2785-2791, https://doi.org/10.1002/jcc.21256.

65. Hanwell, M.D.; Curtis, D.E.; Lonie, D.C.; Vandermeersch, T.; Zurek, E.; Hutchison, G.R. Avogadro: An Advanced Semantic Chemical Editor, Visualization, and Analysis Platform. J. Cheminform. 2012, 4, https://doi.org/10.1186/1758-2946-4-17.

66. Machado, E.F.; Feisser, A.M.; Gonçalves, M.B. A Modelagem Molecular Como Mediadora Da Aprendizagem Da Estrutura e Da Função Da Molécula de DNA. RENOTE 2018, 15, https://doi.org/10.22456/1679-1916.79187.

67. An, J.; Xie, Y.; Feng, Y.; Wu, G. Enhanced Enzyme Kinetic Stability by Increasing Rigidity within the Active Site. J. Biol. Chem. 2014, 289, 79994-8006, https://doi.org/10.1074/jbc.M113.536045.

68. Cheung, J.; Rudolph, M.J.; Burshteyn, F.; Cassidy, M.S.; Gary, E.N.; Love, J.; Franklin, M.C.; Height, J.J. Structures of Human Acetylcholinesterase in Complex with Pharmacologically Important Ligands. Journal of Medicinal Chemistry 2012, 55, 10282-10286, https://doi.org/10.1021/jm300871x.

69. Ahmadi, M.; Jahed Motlagh, M.; Rahmani, A.T.; Zolfagharzadeh, M.M.; Shariatpanahi, P.; Chermack, T.J.; Coons, L.M.; Cotter, J.; Eyiah-Donkor, E.; Poti, V.; Derbyshire, J.; Dolan, T.E.; Fuller, T.; Kishita, Y.; McLellan, B.C.; Giurco, D.; Aoki, K.; Yoshizawa, G.; Handoh, I.C.; Kuhmonen, T.; Kuusi, O.; Lauhakangas, O.; Ruttas-Küttim, R.; Mason-D’Croz, D.; Vervoort, J.; Palazzo, A.; Islam, S.; Lord, S.; Helfgott, A.; Havlok, P.; Peou, R.; Sassen, M.; Veeger, M.; van Soesbergen, A.; Arnell, A.P.; Stuch, B.; Arslan, A.; Lipper, L.; Roper, J.; Tarasti, E.; The Mendeley Support Team; Mendeley Ltd; Dearden, P.; Kowalski, B.; Lowe, J.; Roland, R.; Surridge, M.; Thomas, S.S.; Jones, S.; Travesset-Baro, O.; Gallacheir, B.P.; Jover, E.; RosasCasals, M.; Veenman, S.; Leroy, P.; Zackery, A.; Shariatpanahi, P.; Zolfagharzadeh, M.M.; Pourezzat, A.A.; Lee, C.; Pschorn, U.; Rössler, E.; Sillescu, H.; Kaufmann, S.; Schaefer, D.; Spiess, H.W.; Palierne, J.F.; Seo, Y.; Paeng, K.; Park, S.; Reignier, J.; Favis, B.D.; Maeda, H.; Ueda, M.; Morinaga, T.; Matsumoto, T.; Ma, Z.; Lacroix-Desmazes, P.; O’Reilly, J.M.; Matusinovic, Z.; Shukla, R.; Manias, E.; Hogshead, C.G.; Wilkie, C.A.; Yin, Z.; Koulic, C.; Pagnoulle, C.; Jérôme, R.; Tanaka, T.; Nakatsuru, R.; Kagari, Y.; Saito, N.; Okubo, M.; Sikka, M.; Pellegrini, N.N.; Schmitt, E.A.; Winey, K.I.; Ray, D.K.; Himanshu, A.K.; Sinha, T.P.; SotoFigueroa, C.; Rodríguez-Hidalgo, M.D.R.; Martínez-Magadán, J.M.; Utracki, L.A.; Kamal, M.R.; Shi, G.Z.H.; Rodrigue, D.; Gonzalez-Nüñez, R.; Logothetidis, S.; Zallen, R.; Tsagaropoulos, G.; Eisenberg, A.; Boudenne, A.; Ibos, L.; Candau, Y.; Thomas, S.S.; Spectroscopy, R.; Barlow, J.W.; Paul, D.R.; Ye, Y.S.; Shen, W.C.; Tseng, C.Y.; Rick, J.; Huang, Y.J.; Chang, F.C.; Hwang, B.J.; Braunecker, W.A.; Pintauer, T.; Tsarevsky, N.V.; Kickelbick, G.; Matyjaszewski, K.; Schwahn, D.; Han, C.D.; Freed, K.F.; Dudowicz, J.; Fu, X.; Qutubuddin, S.; Fayt, R.; Jérôme, R.; Teyssié, P.H.; Graebling, D.; Muller, R.; Palierne, J.F.; Chernikova, E.; Terpugova, P.; Bui, C.; Charleux, B.; Fayt, R.; Jerome, R.; Teyssié, P.H.; Cognard, J.; Laborde, J.; Deraeve, C.; Lecoq, L.; Sournia-Saquet, A.; Stigliani, J.L.; Orena, B.S.; Mori, G.; Pratviel, G.; Bernardes-Génisson, V.; Lee, M.; Lodge, T.; Macosko, C.; Heitz, W.; Brügging, W.; Freund, L.; Gailberger, M.; Greiner, A.; Jung, H.; Kampschulte, U.; Nießner, N.; Osan, F.; Schmidt, H.-W.; Wicker, M.; Guo, S.; Ait-Kadi, A.; Jaramillo-Soto, G.; García-Morán, P.R.; Enríquez-Medrano, F.; Maldonado-Textle, H.; Albores-Velasco, M.E.; Guerrero-Santos, R.; Vivaldo-Lima, E.; Ishihara, N.; Seimiya, T.; Kuramoto, M.; Uoi, M.; Rohini, R.; Bose, S. Chem3D 15.0 User Guide. Macromolecules 2005, 24, 1-61.

70. Brown, T. ChemDraw. Sci. Teach. 2014, 81.

71. Barreiro, E.J.; Fraga, C.A.M. Química Medicinal: As Bases Moleculares Da Ação Dos Fármacos, $3^{\mathrm{a}}$. Artmed: Porto Alegre, 2015. 
72. Oliveira, A.M. Introdução a Modelagem Molecular Para Química, Engenharia e Biomédicas: Fundamnetos e Exercícios, $1^{\mathrm{a}}$. Appris: Curitiba, 2018.

73. Batista, G.C.; Lima, A.R.; Crisóstomo, L.C.S.; Marinho, M.M.; Marinho, E.S. Softwares Para o Ensino de Química: Chemsketch Um Poderoso Recurso Didático. Rev. Educ. nterdisciplinar 2016, 5.

74. Schnur, D.M.; Grieshaber, M.V.; Bowen, J.P. Development of an internal searching algorithm for parameterization of the MM2/MM3 force fields. Journal of Computational Chemistry 1991, 12, 844-849, https://doi.org/10.1002/jcc.540120709.

75. Trott, O.; Olson, A.J. AutoDock Vina: Improving the Speed and Accuracy of Docking with a New Scoring Function, Efficient Optimization, and Multithreading. J. Comput. Chem. 2010, 31, 455-461, https://doi.org/10.1002/jcc.21334.

76. Biovia. Dassault Systemes BIOVIA, Discovery Studio Modelling Environment, Release 4.5. Accelrys Software Inc. San Diego 2015.

77. Nascimento, M.d.G.; Zanotto, S.P.; Melegari, S.P.; Moran, P.J.S. Estudos de Proteção Da Célula de Saccharomyces Cerevisiae Para Utilização Em Reações de Redução Em Meio Orgânico. Quim. Nova 2002, 25, 567-571, https://doi.org/10.1590/s0100-40422002000400011.

78. Fonseca, T.N.; Teixeira, P.S.; Moura, E.; Geraldo, A.B.C. Study of Bixin Oxidation By Ionizing Irradiation. In: International Nuclear Atlantic Conference -INAC. 2017.

79. Soares, S.E. Ácidos Fenólicos Como Antioxidantes. Rev. Nutr. 2002, 15, 71-81, https://doi.org/10.1590/s1415-52732002000100008.

80. Paumgartten, F.J.R.; De-Carvalho, R.R.; Araujo, I.B.; Pinto, F.M.; Borges, O.O.; Souza, C.A.M.; Kuriyama, S.N. Evaluation of the developmental toxicity of annatto in the rat. Food and Chemical Toxicology 2002, 40, 1595-1601, https://doi.org/10.1016/S0278-6915(02)00133-3.

81. Lapa Bautista, A.R.P.; Spínola Miranda, M.; Santos Batista, M.; Trindade Moreira, E.L.; Moreira Da Silva, I.; Sena Gomes, I.C. Avaliação Da Toxicidade Oral Subcrônica Da Bixina Para Ratos. Rev. Bras. Ciencias Farm. J. Pharm. Sci. 2004, 40, 229-233, https://doi.org/10.1590/S1516-93322004000200012.

82. Almeida, L.C.; Barbosa, M.S.; de Jesus, F.A.; Santos, R.M.; Fricks, A.T.; Freitas, L.S.; Pereira, M.M.; Lima, Á.S.; Soares, C.M.F. Enzymatic Transesterification of Coconut Oil by Using Immobilized Lipase on Biochar: An Experimental and Molecular Docking Study. Biotechnol. Appl. Biochem. 2020, 1-8, https://doi.org/10.1002/bab.1992.

83. Fonseca, A.M.da; Cavalcante, A.L.G.; Carvalho, R.M.M.; Amaral, J.F.do; Colares, R.P.; Marinho, E.S.; Neto, M.M. Study of the Inhibition Potential of Remdesivir Derivatives on Mpro of SARS-COV-2. Int. J. Res. -Granthaalayah 2020, 8, 164-174, https://doi.org/10.29121/granthaalayah.v8.i11.2020.2342.

84. Arpigny, J.L.; Jaeger, K.E. Bacterial Lipolytic Enzymes: Classification and Properties. Biochem. J. 1999, 343, 177-183, https://doi.org/10.1042/0264-6021:3430177.

85. Reetz, M.T. Biocatalysis in Organic Chemistry and Biotechnology: Past, Present, and Future. J. Am. Chem. Soc. 2013, 135, 12480-12496, https://doi.org/10.1021/ja405051f.

86. Fernandez-Lafuente, R. Lipase from Thermomyces Lanuginosus: Uses and Prospects as an Industrial Biocatalyst. J. Mol. Catal. B Enzym. 2010, 62, 197-212, https://doi.org/10.1016/j.molcatb.2009.11.010.

87. Hevener, K.E.; Zhao, W.; Ball, D.M.; Babaoglu, K.; Qi, J.; White, S.W.; Lee, R.E. Validation of Molecular Docking Programs for Virtual Screening against Dihydropteroate Synthase. J. Chem. Inf. Model. 2009, 49, 444-460, https://doi.org/10.1021/ci800293n.

88. Hassan, N.M.; Alhossary, A.A.; Mu, Y.; Kwoh, C.K. Protein-Ligand Blind Docking Using QuickVina-W with Inter-Process Spatio-Temporal Integration. Sci. Rep. 2017, 7, 1-13, https://doi.org/10.1038/s41598-01715571-7.

89. Olazaran, J.; Garcia, G. Galantamine: A Novel Cholinergic Agent for Alzheimer's Disease [Spanish] Galantamina, Un Nuevo Colinergico Para La Enfermedad de Alzheimer. Neurologia 2002, 17, 429-436.

90. Prvulovic, D.; Hampel, H.; Pantel, J. Galantamine for Alzheimer's Disease. Expert Opin. Drug Metab. Toxicol. 2010, 6, 345-354, https://doi.org/10.1517/17425251003592137. 